\title{
Management of endometrial cancer: current insights and future directions
}

Endometrial cancer rate is increasing worldwide during the last decades (1). In most of the cases, endometrial cancer has a well or moderately differentiated endometrioid histotype at early-stage with a good prognosis. Nevertheless, the evaluation of lymph node status through pelvic and selective para-aortic node dissection $(2,3)$ is an invaluable prognostic factor for targeted adjuvant treatment $(4,5)$. In this scenario, novel strategies are arising in order to make diagnosis as earlier as possible (6), and provide appropriate management for these patients, taking into account the possibility of tailored treatment, even by minimally invasive approach $(7)$. Indeed, the preoperative assessment $(8,9)$ with imaging techniques $(10)$ and endometrial biopsy (11) allows the definition of endometrial cancer stage and grade and its appropriate management (12), especially taking into account potential risk factors (13-15). In this regard, the current role of hysteroscopy for targeted endometrial biopsy (16) is pivotal to minimize misdiagnosis of endometrial cancer and erroneous tumor grading classification (17).

Endometrial cancer may occur in reproductive age, and fertility preservation approaches are mandatory in this population (18) and represent a current challenge (19). This element is of paramount importance, since the surgical treatment, as well as adjuvant strategies, may play all a detrimental role on psychological condition of the woman (20) and should be balanced between radicality and preservation of fertility potential. In addition, the search for novel and costeffective biomarkers (21) are shedding new lights on the topic (22), aiming to identify patients with high-risk of recurrence (23) after radical treatment.

In this scenario, the articles published in this special series can be considered a significant step forward in our knowledge about endometrial cancer and stimulate further discussion among the readers. In particular, the novel pieces of information contained in these articles may lead to important changes in the clinical practice and potential paradigm shifts in the future management of endometrial cancer.

\section{Acknowledgments}

Funding: None.

\section{Footnote}

Provenance and Peer Review: This article was commissioned by the editorial office, Translational Cancer Research, for the series "Endometrial Cancer". The article did not undergo external peer review.

Conflicts of Interest: The author has completed the ICMJE uniform disclosure form (available at http://dx.doi.org/10.21037/tcr2020-ec-15). The series "Endometrial Cancer" was commissioned by the editorial office without any funding or sponsorship. ASL served as the unpaid Guest Editor of the series, and serves as an unpaid editorial board member of Translational Cancer Research from Dec 2019 to Nov 2021. The author has no other conflicts of interest to declare.

Ethical Statement: The author is accountable for all aspects of the work in ensuring that questions related to the accuracy or integrity of any part of the work are appropriately investigated and resolved.

Open Access Statement: This is an Open Access article distributed in accordance with the Creative Commons AttributionNonCommercial-NoDerivs 4.0 International License (CC BY-NC-ND 4.0), which permits the non-commercial replication and distribution of the article with the strict proviso that no changes or edits are made and the original work is properly cited (including links to both the formal publication through the relevant DOI and the license). See: https://creativecommons.org/licenses/by-nc$\mathrm{nd} / 4.0 \%$. 


\section{References}

1. Vitale SG, Capriglione S, Zito G, et al. Management of endometrial, ovarian and cervical cancer in the elderly: current approach to a challenging condition. Arch Gynecol Obstet 2019;299:299-315.

2. Casarin J, Bogani G, Piovano E, et al. Survival implication of lymphadenectomy in patients surgically treated for apparent earlystage uterine serous carcinoma. J Gynecol Oncol 2020;31:e64.

3. Della Corte L, Giampaolino P, Mercorio A, et al. Sentinel lymph node biopsy in endometrial cancer: state of the art. Transl Cancer Res 2020;9:7725-33.

4. Cignini P, Vitale SG, Laganà AS, et al. Preoperative work-up for definition of lymph node risk involvement in early stage endometrial cancer: 5-year follow-up. Updates Surg 2017;69:75-82.

5. Pinelli C, Artuso V, Bogani G, et al. Lymph node evaluation in endometrial cancer: how did it change over the last two decades? Transl Cancer Res 2020;9:7778-84.

6. Casarin J, Bogani G, Serati M, et al. Presence of Glandular Cells at the Preoperative Cervical Cytology and Local Recurrence in Endometrial Cancer. Int J Gynecol Pathol 2020;39:522-8.

7. Capozzi VA, Rosati A, Uccella S, et al. Role of uterine manipulator during laparoscopic endometrial cancer treatment. Transl Cancer Res 2020;9:7759-66.

8. Török P, Krasznai Z, Molnár S, et al. Preoperative assessment of endometrial cancer. Transl Cancer Res 2020;9:7746-58.

9. Lukanović D, Matjašič M, Kobal B. Accuracy of preoperative sampling diagnosis for predicting final pathology in patients with endometrial carcinoma: a review. Transl Cancer Res 2020;9:7785-96.

10. Franchi M, Garzon S, Zorzato PC, et al. PET-CT scan in the preoperative workup of early stage intermediate- and high-risk endometrial cancer. Minim Invasive Ther Allied Technol 2020;29:232-9.

11. Chiofalo B, Mazzon I, Di Angelo Antonio S, et al. Hysteroscopic Evaluation of Endometrial Changes in Breast Cancer Women with or without Hormone Therapies: Results from a Large Multicenter Cohort Study. J Minim Invasive Gynecol 2020;27:832-9.

12. Terzic MM, Aimagambetova G, Terzic S, et al. Current role of Pipelle endometrial sampling in early diagnosis of endometrial cancer. Transl Cancer Res 2020;9:7716-24.

13. Scioscia $M$, Noventa $M$, Laganà AS. Abnormal uterine bleeding and the risk of endometrial cancer: Can subendometrial vascular ultrasound be of help to discriminate cancer from adenomyosis? Am J Obstet Gynecol 2020;223:605-6.

14. Drizi A, Djokovic D, Laganà AS, et al. Impaired inflammatory state of the endometrium: a multifaceted approach to endometrial inflammation. Current insights and future directions. Menopausal Rev 2020;19:90-100.

15. Laganà AS, Scioscia M. Endometrial cancer in women with adenomyosis: An underestimated risk? Int J Fertil Steril 2020;14:260-1.

16. Vitale SG, Riemma G, Carugno J, et al. Hysteroscopy in the management of endometrial hyperplasia and cancer in reproductive aged women: new developments and current perspectives. Transl Cancer Res 2020;9:7767-77.

17. Ferrari F, Forte S, Arrigoni G, et al. Impact of endometrial sampling technique and biopsy volume on the diagnostic accuracy of endometrial cancer. Transl Cancer Res 2020;9:7697-705.

18. Topçu HO, Kaya C, Oral E. Fertility issue in early stage endometrial cancer patients. Transl Cancer Res 2020;9:7797-808.

19. Vitale SG, Rossetti D, Tropea A, et al. Fertility sparing surgery for stage IA type I and G2 endometrial cancer in reproductiveaged patients: evidence-based approach and future perspectives. Updates Surg 2017;69:29-34.

20. Laganà AS, La Rosa VL, Rapisarda AM, et al. Comment on: "Needs and priorities of women with endometrial and cervical cancer". J Psychosom Obstet Gynaecol 2017;38:85-6.

21. Benati M, Montagnana M, Danese E, et al. Aberrant Telomere Length in Circulating Cell-Free DNA as Possible Blood Biomarker with High Diagnostic Performance in Endometrial Cancer. Pathol Oncol Res 2020;26:2281-9.

22. Králíčková M, Vetvicka V, Laganà AS. Endometrial cancer—is our knowledge changing? Transl Cancer Res 2020;9:7734-45.

23. Huang YJ, Li BL. The significance of plasma D-dimer level in predicting high risk factors of endometrial cancer. Transl Cancer Res 2020;9:7688-96. 


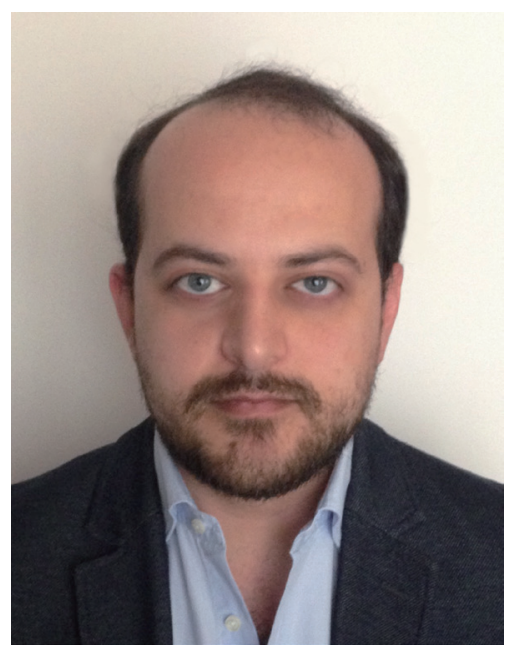

Antonio Simone Laganà

Antonio Simone Laganà

Department of Obstetrics and Gynecology, "Filippo Del Ponte" Hospital, University of Insubria, Varese, Italy. (Email: antoniosimone.lagana@uninsubria.it) Submitted Nov 13, 2020. Accepted for publication Nov 17, 2020. doi: $10.21037 /$ tcr-2020-ec-15

View this article at: http://dx.doi.org/10.21037/tcr-2020-ec-15

Cite this article as: Laganà AS. Management of endometrial cancer: current insights and future directions. Transl Cancer Res 2020;9(12):7685-7687. doi: 10.21037/tcr-2020-ec-15 